\title{
Retinal detachment associated with atopic dermatitis
}

\author{
Masayo Takahashi, Kiyoshi Suzuma, Izumi Inaba, Yuichiro Ogura, Kozo Yoneda, \\ Hiroyuki Okamoto
}

\begin{abstract}
Background-Retinal detachment associated with atopic dermatitis, one of the most common forms of dermatitis in Japan, has markedly increased in Japan in the past 10 years. To clarify pathogenic mechanisms of retinal detachment in such cases, we retrospectively studied clinical characteristics of retinal detachment associated with atopic dermatitis.

Methods-We examined the records of 80 patients (89 eyes) who had retinal detachment associated with atopic dermatitis. The patients were classified into three groups according to lens status: group $\mathbf{A}$, eyes with clear lenses (40 eyes); group $B$, eyes with cataract ( 38 eyes), and group $C$, aphakic or pseudophakic eyes (11 eyes).

Results-No significant differences were noted in the ratio of males to females, age distribution, refractive error, or characteristic of retinal detachment among the three groups. The types of retinal breaks, however, were different in eyes with and without lens changes. While atrophic holes were dominant in group $A$, retinal dialysis was mainly seen in groups $B$ and $C$.

Conclusion-These findings suggested that anterior vitreoretinal traction may play an important role in the pathogenesis of retinal breaks in eyes with atopic cataract and that the same pathological process may affect the formation of cataract and tractional retinal breaks in patients with atopic dermatitis.

(Br F Ophthalmol 1996; 80: 54-57)
\end{abstract}

Atopic dermatitis, one of the most common forms of dermatitis in Japan, has recently increased in incidence. As many as $30 \%$ of the students in Japan are reportedly affected with some degree of atopic dermatitis. ${ }^{1}$ The adult type of atopic dermatitis especially (older than 10 years) has markedly increased in the past 10 years. ${ }^{2}$ The number of affected patients aged from 11 to 30 years was three times higher in 1985 than in 1975, while the number of children younger than 11 years with atopic dermatitis has not increased. ${ }^{2}$

Atopic dermatitis is associated with many ocular complications such as conjunctivitis, keratoconus, iritis, cataract, and retinal detachment. ${ }^{3}$ Case reports of retinal detachment associated with atopic dermatitis ${ }^{4-29}$ have offered several ideas about its pathogenesis, including trauma, 514202427 inflammation, 1216 and shock organ theory (the tissue of mesodermal origin served as the shock organ). ${ }^{7}$ To clarify what types of retinal breaks are characteristic of the atopic related retinal detachment, and to clarify pathogenic mechanisms of retinal detachment in such cases, we studied, retrospectively, clinical characteristics of retinal detachment associated with atopic dermatitis.

\section{Materials and methods}

We examined the records of 89 eyes from 80 patients, with retinal detachment associated with atopic dermatitis, who were treated at Kyoto University Hospital from January 1970 to July 1993. All patients were previously diagnosed as having atopic dermatitis by dermatologists. They were also suffering from the facial dermatitis for more than a year before the first examination in our clinic. All patients were followed up for at least 3 months. The patients were classified into three groups according to lens status: group $\mathrm{A}$, eyes with clear lenses; group B, eyes with cataract; group C, aphakic or pseudophakic eyes. Characteristics of retinal breaks and retinal detachments were investigated in each group.

Retinal breaks were classified into four types: atrophic retinal holes, tractional retinal tears, retinal dialysis, and breaks in the ciliary epithelium of the pars plana.

Configuration of the retinal detachment was divided into two types: bullous and shallow detachments. The extent of retinal detachment was expressed by the number of affected quadrants.

Diathermy or cryoretinopexy was applied to seal retinal breaks, and a scleral buckling procedure was performed. Closed vitrectomy was combined with scleral buckling in cases with complicated retinal detachment that had vitreoretinal traction or total retinal detachment without apparent breaks. Five eyes received vitrectomy at the first operation. The operation was considered anatomically successful if the retina was still reattached at the final examination at least 6 months after the operation. Two eyes that had been initially treated at another hospital were excluded.

The relations between categorical variables were examined using the Kruskal-Wallis test. The surgical results were examined using $\chi^{2}$ analysis. Differences were considered significant when the probability of their occurrence by chance was less than $5 \%$.

\section{Results}

The numbers of retinal detachments associated with atopic dermatitis have increased 


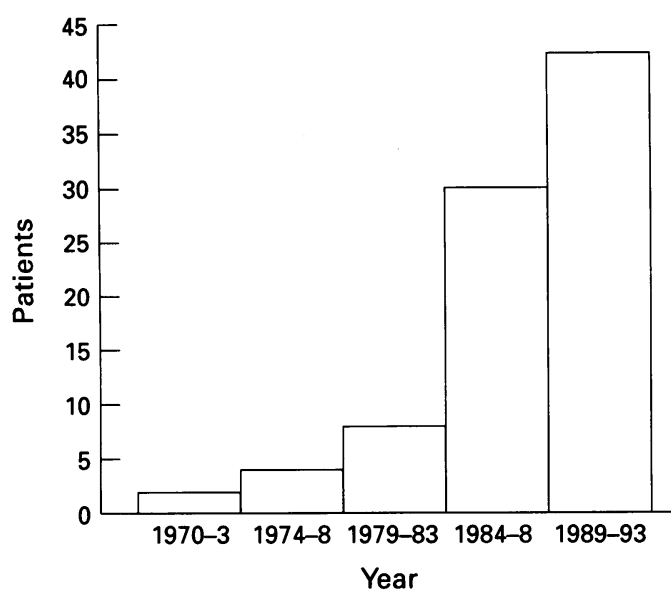

Figure 1 Numbers of retinal detachments associated with atopic dermatitis treated at Kyoto University Hospital from 1970 to 1993

remarkably since 1984 (Fig 1), while the number of retinal detachments treated in our department has not changed and was around 300 each year.

The general characteristics of the 89 eyes of 80 patients included in this study have been listed in Table 1 . In nine patients, both eyes were involved. A greater proportion of males (56 eyes, 63\%) was observed. The patients ranged in age from 7 to 65 years (average 23.2 years). There were 40 eyes without cataract (group A), 38 eyes with cataract (group B), and 11 aphakic eyes (group C). The proportion of males to females within each group (Table 1) was not statistically different $(p=0.422)$. The mean ages (Table 1$)$ of each group were 23.3 (SD 13.1) years (group A), $21 \cdot 1(9 \cdot 1)$ years (group B), and $20.9(8 \cdot 0)$ years (group $\mathrm{C}$ ). There was no statistically significant difference in age distribution among the three groups $(p=0 \cdot 6161)$. No apparent differences were observed between the three groups with regard to the severity of the atopic dermatitis. Table 2 shows the configuration of the retinal detachment of each group. The proportion of bullous and shallow retinal detachments was not different between groups $\mathrm{A}$ and B. The bullous detachment was predominant in group $\mathrm{C}$, but the difference was not statistically significant $(p=0.0866)$. The extent of the retinal detachment (Table 2) was wider in group $\mathrm{C}$, but the difference was not significant $(p=0.0583)$.

The characteristics of retinal breaks for each group have been listed in Table 3. Atrophic holes were dominant in group A (22 eyes, $54 \%$ ), but not in group B (six eyes, $16 \%$ ) or group C (0 eyes).

Retinal dialyses were mainly seen in groups B (12 eyes, 32\%) and C (six eyes, 55\%), but

Table 1 General characteristics of patients included in this study: group $A$, eyes without cataract; group $B$, eyes with cataract; group $C$, aphakic eyes

\begin{tabular}{lllll}
\hline $\begin{array}{l}\text { Patient } \\
\text { group }\end{array}$ & $\begin{array}{l}\text { Male } \\
(\%)\end{array}$ & $\begin{array}{l}\text { Female } \\
(\%)\end{array}$ & $\begin{array}{l}\text { Age (SD) } \\
\text { (year) }\end{array}$ & $\begin{array}{l}\text { Total } \\
(\%)\end{array}$ \\
\hline A & $27(68)$ & $13(32)$ & $23 \cdot 3(13 \cdot 1)$ & $40(45)$ \\
B & $21(55)$ & $17(45)$ & $21 \cdot 1(9 \cdot 1)$ & $38(43)$ \\
C & $8(73)$ & $3(27)$ & $20 \cdot 9(8 \cdot 0)$ & $11(12)$ \\
Total & $56(63)$ & $33(37)$ & $23 \cdot 2(10 \cdot 9)$ & $89(100)$ \\
\hline
\end{tabular}

Table 2 Configuration and extent of retinal detachments in study patients

\begin{tabular}{|c|c|c|c|c|c|c|}
\hline \multirow{2}{*}{$\begin{array}{l}\text { Patient } \\
\text { group }\end{array}$} & \multicolumn{2}{|c|}{ Configuration (\%) } & \multicolumn{4}{|c|}{ Affected quadrants (\%) } \\
\hline & Bullous & Shallow & 1 & 2 & 3 & 4 \\
\hline $\begin{array}{l}\text { A } \\
\text { B } \\
\text { C } \\
\text { Total }\end{array}$ & $\begin{array}{r}18(45) \\
18(47) \\
9(82) \\
45(51)\end{array}$ & $\begin{array}{r}22(55) \\
20(53) \\
2(18) \\
44(49)\end{array}$ & $\begin{array}{r}14(35) \\
11(29) \\
2(18) \\
27(30)\end{array}$ & $\begin{array}{r}20(50) \\
16(42) \\
3(27) \\
39(44)\end{array}$ & $\begin{array}{r}4(10) \\
7(18) \\
2(18) \\
13(15)\end{array}$ & $\begin{array}{c}2(5) \\
4(11) \\
4(37) \\
10(11)\end{array}$ \\
\hline
\end{tabular}

not in group A (two eyes, $5 \%$ ). The difference between the distributions of retinal break types of each group was statistically significant $(p=0 \cdot 0006)$.

Retinal reattachment was obtained in 65 eyes $(75 \%)$ at initial surgery and in 84 eyes $(97 \%)$ eventually (Tables 4 and 5 ). All retinal detachments caused by atrophic holes, tractional tears, or retinal dialysis were eventually reattached. On the other hand, retinal detachment with tears in the ciliary epithelium showed a significantly lower final success rate $(p=0 \cdot 0006)$. Retinal detachments in eyes without cataract (group A) had a 100\% success rate. A significant difference was found in the success rate at the initial operation among the three groups $(p=0.0060)$.

\section{Discussion}

Our findings correlated with the recent increase of retinal detachments associated with atopic dermatitis that have been reported in Japan. ${ }^{20-24}$ This growth may have been directly related to the marked increase in the adult population with atopic dermatitis in Japan. ${ }^{2}$ It was interesting that male patients accounted for two thirds of the retinal detachments in this study, while the population of male to female patients with atopic dermatitis was almost the same. ${ }^{2}$

Several theories have been given about the pathogenesis of retinal detachment associated with atopic dermatitis. Cordes and CorderoMoreno reported four cases they thought were caused by trauma. ${ }^{5}$ Ideta and others reported cases in which trauma was highly suspicious. ${ }^{142024}$ Some patients actually suffering from dermatitis on the face had a habit of slapping themselves on the eye as a result of severe itching. The breaks at the most peripheral retina resembled those caused by obvious trauma. Many patients, however, did not have this habit. It is possible that trauma was a contributing factor but it probably was not the entire explanation.

Balyeat thought that the retinal detachment resulted from oedema of the retina, ${ }^{4}$ and Mylius thought the cause was vascular change

Table 3 Characteristics of retinal breaks

\begin{tabular}{|c|c|c|c|c|c|}
\hline $\begin{array}{l}\text { Patient } \\
\text { group }\end{array}$ & $\begin{array}{l}\text { Atrophic } \\
\text { hole }(\%)\end{array}$ & $\begin{array}{l}\text { Tractional } \\
\text { tear }(\%)\end{array}$ & $\begin{array}{l}\text { Dialysis } \\
(\%)\end{array}$ & $\begin{array}{l}\text { Break } \\
\text { in } C B \\
\text { epithelium } \\
(\%)^{\star}\end{array}$ & $\begin{array}{l}\text { Breaks } \\
\text { not found } \\
(\%)\end{array}$ \\
\hline $\begin{array}{l}\text { A } \\
\text { B } \\
\text { C } \\
\text { Total }\end{array}$ & $\begin{array}{c}22(55) \\
6(16) \\
0(0) \\
28(31)\end{array}$ & $\begin{array}{r}11(27) \\
9(24) \\
2(18) \\
22(25)\end{array}$ & $\begin{array}{c}2(5) \\
12(32) \\
6(55) \\
20(22)\end{array}$ & $\begin{array}{l}0(0) \\
2(5) \\
0(0) \\
2(2)\end{array}$ & $\begin{array}{r}5(13) \\
9(24) \\
3(27) \\
17(19)\end{array}$ \\
\hline
\end{tabular}


Table 4 Surgical results for each type of retinal break

\begin{tabular}{lllllll}
\hline $\begin{array}{l}\text { Surgical } \\
\text { results }\end{array}$ & $\begin{array}{l}\text { Atrophic } \\
\text { hole (\%) }\end{array}$ & $\begin{array}{l}\text { Tractional } \\
\text { tear (\%) }\end{array}$ & $\begin{array}{l}\text { Dialysis } \\
(\%)\end{array}$ & $\begin{array}{l}\text { Break in } \\
\text { CB (\%)* }\end{array}$ & $\begin{array}{l}\text { Breaks not } \\
\text { found (\%) }\end{array}$ & $\begin{array}{l}\text { Total } \\
(\%)\end{array}$ \\
\hline Initial & $24(86)$ & $18(82)$ & $12(63)$ & $1(50)$ & $10(63)$ & $65(75)$ \\
Final & $28(100)$ & $22(100)$ & $19(100)$ & $1(50)$ & $14(88)$ & $84(97)$ \\
\hline
\end{tabular}

${ }^{\star} \mathrm{CB}=$ ciliary body. that are characteristic of atopic dermatitis. These breaks can be related to the intense inflammation produced by the abnormal immune reaction of patients with atopic dermatitis. The inflammations after cataract surgery were so severe in the atopic patients that they caused contraction of the remaining posterior capsules and the anterior portion of the vitreous. ${ }^{21}$ This might produce traction forces in the ciliary epithelium via zonules or to the peripheral retina and result in breaks. In our study, the breaks in the ciliary epithelium were not found in the aphakic patient group. Since the breaks in the ciliary epithelium were hard to find through the remaining posterior capsule, they might not be classified properly.

Retinal dialysis may result directly by slapping the eye, since the force would strongly affect that area of the eye under blunt trauma. However, it is not explained completely by trauma itself because not all the patients have the habit of slapping the eyes. The abnormal immune reaction after chronic blunt trauma, such as rubbing eyes, might cause inflammation in the peripheral retina. For example, chronic cyclitis may result and affect the anterior vitreous, which would lead to contractions that would produce retinal breaks. On the other hand, the inflammation would affect the posterior capsule of the lens and result in cataracts. In this theory it is likely that the formation of cataracts and breaks in patients with atopic dermatitis follows the same pathological process that may deleteriously affect both the lens and the vitreous.

Our study suggested that retinal detachments associated with atopic dermatitis consist of some groups of different pathogenesis. One group has retinal detachments with atrophic holes similar to those commonly seen in young patients without atopic dermatitis. In those patients who have atrophic holes, the atopic dermatitis may overlap by chance and not be associated with the pathogenesis, or the atopic dermatitis may somehow enhance the pathogenesis. There may be a group of patients who have retinal dialysis resulting directly from slapping the eyes. There may also be a group of patients who have retinal tears caused by contraction of the posterior capsule after cataract surgery. However, the most characteristic retinal breaks produced by atopic change, which can be called 'atopic related retinal breaks', might be tractional breaks at the far periphery of the retina associated with cataract. We speculate that the same pathological process may affect the atopic cataract and the atopic related retinal breaks.

1 Tokuda Y. Atopic dermatitis associated with retinal detachment. Nihon Iji Shinpo 1992; 3567: 24-31.

2 Nishioka K. Adult type of atopic dermatitis. fpn $f$ Clin Dermatol 1991; 33: 413-8.

3 Rich LF, Hanifin JM. Ocular complications of atopic dermatitis and other eczemas. Int Ophthalmol Clin 1985; 25: matitis

4 Balyeat RM. Complete retinal detachment. Am $f$ Ophthalmol 1937; 20: 580-2.

5 Cordes FC, Cordero-Moreno R. Atopic cataracts: report of 4 cases. Am F Ophthalmol 1946; 29: 402-7.

6 Mylius K. Doppelseitige spontane Netzhautablosung bei 2 jugendlichen, seit Jahren an Neurodermitis disseminata leidenden Patienten. Klin Monatsbl Augenheilkd 1949;
115: 247-50.

\begin{tabular}{lllll}
\hline $\begin{array}{l}\text { Surgical } \\
\text { results }\end{array}$ & $\begin{array}{l}\text { Group } \\
A(\%)\end{array}$ & $\begin{array}{l}\text { Group } \\
B(\%)\end{array}$ & $\begin{array}{l}\text { Group } \\
C(\%)\end{array}$ & $\begin{array}{l}\text { Total } \\
(\%)\end{array}$ \\
\hline Initial & $35(88)$ & $26(70)$ & $4(40)$ & $65(75)$ \\
Final & $40(100)$ & $35(95)$ & $9(90)$ & $84(97)$ \\
\hline
\end{tabular}


7 Coles RS, Laval J. Retinal detachments occurring in cataract associated with neurodermatitis. Arch Ophthalmol cataract associated

8 Hurlbut WB, Domonkos AN. Cataract and retinal detachment associated with atopic dermatitis. Arch Ophthalmol 1954; 52: 852-7.

9 Vetter G. Eine wetere Beobachtung von doppelseitiger Amotio bei Cataracta syndermatologica bilateralis. Klin Monatsbl Augenheilkd 1957; 130: 264-5.

10 Spencer WH, Fisher JJ. The association of keratoconus with atopic dermatitis. Am f Ophthalmol 1959; 47: 332-4.

11 Klemens F. Dermatose, Katarakt und Ablatio retinae. Klin Monatsbl Augenheilkd 1962; 140: 657-63.

12 Jutte A, Lemke L. Amotio-Katarakt-Keratokonus als okularer Symptomenkomplex bei endogenem Ekzem. Klin Monatsbl Augenheilkd 1965; 147: 12-25.

13 Ingram RM. Retinal detachment associated with atopic dermatitis and cataract. Br $\mathcal{\text { Ophthalmol } 1 9 6 5 ; 4 9 : 9 6 - 7 .}$

14 Ideta $\mathrm{H}$, Ishikawa $M$. Two cases of retina detachment in atopic dermatitis. Fpn Rev Clin Ophthalmol 1983; 77: 773-6.

15 Garrity JA, Liesegang TJ. Ocular complications of atopic

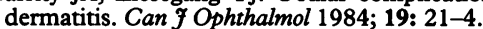

16 Katsura H, Hida T. Atopic dermatitis: retinal detachment associated with atopic dermatitis. Retina $1984 ; 4: 148-51$.

17 Morita H, Sato A. Keratoconus, cataract and retinal detachment in atopic dermatitis. Ophthalmology 1987; 29: 1259-63.

18 Ijjima Y, Wagai K, Matsuura Y, Ueda M, Miyazaki I. Retinal detachment with breaks in the pars plicata of the ciliary body. Am $₹$ Ophthalmol 1989; 108: 349-55.

19 Ideta $H$. Retinal detachment in atopic dermatitis. Ophthalmology 1989; 31: 191-4.
20 Nagasaki H, Ideta H, Uemura A, Ishikawa M, Yoshino Y. Trauma-induced retinal detachment with atopic dermatiTrauma-induced retinal detachment with ato
tis. Ipn $\mathcal{f}$ Clin Ophthalmol 1989; 43: 725-8.

21 Moritera T, Tanaka Y, Tanaka Y, Izutani M, Imamura S, Ogino N. Association of atopic cataract and retinal detachment. fpn $\mathcal{f}$ Clin Ophthalmol 1989; 43: 734-7.

22 Takai K, Deguchi J, Kono T, Takaura C, Uyama $M$ Rhegmatogenous retinal detachment associated with atopic dermatitis. Ipn $\mathcal{f}$ Clin Ophthalmol 1989; 43: 897-900.

23 Okudaira A, Okinami S. Retinal detachment associated with atopic dermatitis. Fpn Rev Clin Ophthalmol 1989; 83: with atop

24 Ashizawa E, Norose K, Hashizume H, Segawa K. Retinal detachment caused by eye tapping associated with atopic dermatitis. Folia Ophthalmol fpn 1989; 40: 2994-8.

25 Azuma N. Rhegmatogenous retinal detachment in children. Ipn Rev Clin Ophthalmol 1991; 33: 637-40.

26 Imai $Y$, Ninomiya $H$, Kobayashi $Y$, Tanaka $M$, Taneda $A$ Kawakita M. The clinical studies of retinal detachment and cataract associated with atopic dermatitis. fpn $\mathcal{f}$ Clin Ophthalmol 1993; 47: 774-5.

27 Matsuo N, Matsuo T, Shiraga F. Photoreceptor outer segments in the aqueous humor of patients with atopic derments in the aqueous humor of patients with atopic der115: $21-5$.

28 Hirano S, Katoh N, Kishimoto S, Yasuno H, Ikebe H, Akagi Y. Cataract in atopic dermatitis with facial involvement. F Dermatol Sci 1993; 6: 94-6.

29 Ogino N. Topography of retinal breaks associated with retinal detachment. I Retinal holes in lattice degeneration. Acta Soc Ophthalmol fpn 1979; 83: 555-60. 